\title{
Characterization of milk production and composition of four exotic goat breeds in Brazil
}

\author{
A.M.B.O. Lôbo ${ }^{a}, *$ R.N.B. Lôbo ${ }^{a}$, O. Facóa ${ }^{\text {, V. Souza }}{ }^{a}$, A.A.C. Alves ${ }^{b}$, A.C. Costa $^{c}$, \\ M.A.M. Albuquerque ${ }^{c}$

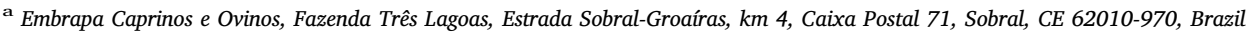 \\ b São Paulo State University, Rua Quirino de Andrade, 215, São Paulo, SP 01049-010, Brazil \\ ' Vale do Acaraú State University, Avenida da Universidade, 850, Betânia Sobral, CE 62040-370, Brazil
}

\section{A R T I C L E I N F O}

\section{Keywords:}

Lactose proportion

Alpine

Anglo Nubian

Saanen

Toggenburg

\begin{abstract}
A B S T R A C T
Milk production traits, milk composition and somatic cell count (SCC) from exotic dairy goats were characterized in tropical climate using data from Dairy Goats Breeding Program. The breeds analyzed are distributed in two regions of Brazil (Southeast and Northeast). The Alpine, Saanen and Toggenburg (raised in Southeast) breeds were compared among themselves and with the breeds of Northeast (Anglo Nubian and Saanen). This study demonstrated that milk yield, 305-day lactation yield, lactation length and daily milk yield were influenced by the genetic of animal (breed) and the environmental conditions, such as flock, month and year of production. These same effects affected the milk composition and SCC which also were influenced by physiological stages of the does (lactation and test-day milk order). There were differences in milk composition between the breeds. This may be a result of diet and chemical composition of the pasture feeding the animals, as well as others genetic and environmental factors. The global averages for proportion of lactose were below of the minimum limits established by the Brazilian Ministry of Agriculture, Livestock and Food Supply. The average of SCC was above one million of cells/mL. This study is the first work of characterization of exotic breeds in tropical climate with a database derived of official milk recording.
\end{abstract}

\section{Introduction}

The goat milk is especially important in developing countries with tropical and subtropical climates. The milk production in these countries is mostly obtained of goats from imported breeds, such as Saanen, Toggenburg, Alpine and Anglo Nubian (FAO, 2007). These breeds were imported to Brazil in the 1980s and today they are the main dairy animals of the country. The milk production these breeds, in Brazil, have its origin in two regions: Northeast and Southeast. In 2005, Embrapa Goat and Sheep began the Dairy Goat Breeding Program ("Programa de Melhoramento Genético de Caprinos Leiteiros" Capragene ${ }^{\circ}$ ) and implemented the first progeny test and official milk recording to Saanen, Alpina and Anglo Nubian breeds (Lôbo et al., 2010; Facó et al., 2011).

Until today there is no phenotypic characterization of dairy goats in the country, although there are studies that estimated the means of the milk traits. However, these means were estimated from one or a few flocks in a certain period of time stationary (single lactation, one year, etc.) or sample taken from the cooling tank (Ciffoni, 1998; Gonçalves et al., 2001, 2002; Irano et al., 2012; Ribeiro et al., 2000; Souza et al., 2009; Tholon, 2000). The averages obtained in this way are not sufficient to characterize a parameter of the population. Therefore this study was launched with the aim of characterize the milk production, chemical composition (macro elements) and the somatic cell count from exotic goats in two regions of Brazil with a database from official milk recording after ten years his execution. This information will be useful to support public policies, industry and decisions-making in breeding programs.

\section{Material and methods}

\subsection{Official milk recording}

Daily milk control measured by the official milk recording of Capragene ${ }^{\star}$ was used for the characterization of representative average values of the traits total milk yield (MY), 305-day lactation yield (LY305), lactation length (LL), daily milk yield (DMY), composition of protein (PRO), fat, lactose (LAC) and total solids (TS), and somatic cell

\footnotetext{
* Corresponding author.

E-mail addresses: ana.lobo@embrapa.br, oliveiraana@yahoo.com.br (A.M.B.O. Lôbo).
} 
count (SCC) od the Saanen, Alpine, Toggenburg and Anglo Nubian breeds. The official milk recording was started in 2006 and it realized as legislation pertinent of the Brazilian Ministry of Agriculture, Livestock and Food Suplly and international standards (ICAR, 2011). Initially milk recording were performed monthly and from July 2012 came to be bimonthly. They were performed by certified technicians in random days not reported to the breeder as official milk recording regulations. Milk measurement was taken in all lactating animals twice a day (morning and evening milking). Data used in this study came from 28 flocks. Of these, 24 are located in the Southeast Brazil, in its four states (Espírito Santo, Minas Gerais, Rio de Janeiro and São Paulo) and the other four flocks are located in two states in the Northeast Brazil, one in Ceará and three in Bahia (Fig. 1). In Southeast, intensive system with animals in confinement fed with concentrate were predominant, while in the Northeast the animals generally grazed on native forest (Caatinga) during the rainy season (January to May) and remained the rest of the year in semi confinement systems. These differences in management style are from regional differences pertaining both to climate as forage availability. Flocks of Southeast are distributed in regions of subtropical and tropical altitude climate (dry winter and humid summer), mountainous, which annual medium temperature ranges from $18{ }^{\circ} \mathrm{C}$ to $24^{\circ} \mathrm{C}$ and annual medium precipitation are above $1500 \mathrm{~mm}$. The breeds evaluated in this region were Alpine, Saanen and Toggenburg. Northeastern flocks are located in regions of semi-arid tropical climate (tending to dry due to the irregularity of the action of the masses of air) that showed annual medium temperatures above $25^{\circ} \mathrm{C}$ and annual medium precipitation lower than $800 \mathrm{~m}$. The breeds Saanen and Anglo Nubian were evaluated in this region.

\subsection{Milk sample}

The analysis of SCC and total solids was started in 2002 and that of lactose in 2006. Individual milk samples were collected in plastic tube with preservative bronopol ${ }^{\circ}$ to determine the milk composition and SCC. Milk samples were analyzed by Clínica do Leite laboratory (São Paulo). The SCC and the milk composition were determined by flow cytometry (IDF Standard 148-2; IDF, 2006) and infrared (IDF Standard 141; IDF, 2013), respectively. The equipment was calibrated for analysis of raw cow's milk as national standard established by Ministry of Agriculture, Livestock and Food Suplly.

\subsection{Statistical analysis}

Records used in this study refer to daily controls (1-23 orders), measured between 1998 and 2014, from goats of the first until seventh lactation, and milked one to two times a day. Data before 2006 came from research herds since official milking records in private herds started in this year. Were considered in the analysis only lactations already finished and those considered valid, i.e., lactation length with a minimum of 150 days and a maximum of 749 days, and the interval between outset of lactation and the first milk recording less than 75 days (as recommended by ICAR, 2011). The traits MY, LY305, LL and DMY were analyzed in 3888 lactations and SCC and milk composition in more than 8000 controls of distinct orders within of the lactations.

The means of traits were calculated by the method of least squares and the comparison of breeds by the Tukey-Kramer test $(\mathrm{P}<0.05)$, according to statistical models described below, adjustment for all fixed effects.

Fat, PRO, LAC, TS and SCC ${ }^{1}=\mu+$ effect of breed + effect of flock within breed + effect of the milking number (number of daily milking; 1 or 2$)+$ effect of the test-day milk order within the lactation (1-23)

+ effect of the month of milk recording + effect of the year of milk

\footnotetext{
${ }^{1}$ SCC was analyzed after logarithmic transformation.
}

recording + effect of lactation order (1st-7th order).

PL, PL305, DL and PDL $=\mu+$ effect of breed + effect of flock within breed + effect of birth month + effect of year of birth + effect of litter type with six levels (one male, one female, two male, two female, one male and female, others) + lactation order (1st-7th order).

Despite there was genetic connectedness among the flocks, Saanen animals from Northeast were considered as a different breed from those Saanen animals of the Southeast region because they not went through the same selection process and they are handled in completely different conditions.

\section{Results}

All effects analyzed in the model were significant $(\mathrm{P}<0.01)$ for the traits MY, LY305, LL and DMY, except $(P>0.05)$ the effect of litter type for MY and LL (Table 1) and month of the year to DMY (Table 2). LY305 and DMY were higher in the second lactation and lower in the seventh lactation. There was a trend that LY305 and DMY were higher in does kidded single birth (one male or one female). Higher MY, LY305 and LL tended to happen in the mid of the year (June). Differences among the years were observed for the traits MY, LY305, LL and DMY (Table 3).

There were no differences in the MY, LY305, LL and DMY for the breeds Alpine, Saanen and Toggenburg reared in the Southeast region of the Brazil (Table 1). The Anglo Nubian breed showed lower production (MY, LY305, LL and DMY) than Saanen and Alpine breeds from Southeast region. There were no significant $(P>0.05)$ differences between Anglo Nubian and Saanen breeds raised in the Northeast region. The LY305 and DMY of the Saanen flock in the Northeast region were less than half those observed in Southeast flocks, with LL mean 46 days lower.

The effects included in the model for the proportion of protein, fat, lactose and total solids and SCC also were significant $(P<0.01)$, except breed for lactose composition (Table 4) and test-day milk order for protein composition (Table 5). Higher values for the studied milk components tended to be observed in the first and sixth lactation, while the SCC values increased with the lactation order. Higher contents of fat, protein, total solids and SCC were verified in does milked once a day. The middle months of the year tended to have the higher values for the studied milk components (Table 6). The SCC values also oscillated during the months of the year. SCC and all traits related to milk composition (Fat, PRO, LAC and TS) varied along the years (Table 7).

The Anglo Nubian had the highest means of the milk composition, except for the lactose percentage, compared to other breeds (Table 4). The milk of Saanen from Northeast region has smaller proportion of fat, protein and total solids than those observed in the milk of Alpine and Saanen from Southeast region. There was no difference in the average proportion of these components between the Saanen and Alpine breeds raised in Southeast region. The average proportion of milk constituents in the Saanen animals raised in Southeast was higher than those observed in Saanen animals raised in the Northeast region.

The global non-transformed and non-adjusted average of SCC was $1,457,097$ cells $/ \mathrm{mL}$, and the non-transformed and non-adjusted averages for Alpine, Saanen and Toggenburg from Southeast and for Saanen and Anglo Nubian from Northeast were close to $1,800,000$ cells $/ \mathrm{mL}, \quad 1,600,000$ cells $/ \mathrm{mL}, \quad 1,600,000$ cells $/ \mathrm{mL}$, 700,000 cells $/ \mathrm{mL}$ and $1,200,000$ cells/mL, respectively. Considering the adjusted and transformed averages, the breeds raised in Southeast region did not differ and showed higher values of SCC than those verified in the Anglo Nubian and Saanen breeds reared in the Northeast, with no difference between these last two (Table 4).

The effects of the flock within breed were significant $(P<0.01)$ for all traits (MY, LY305, LL, DMY, fat, protein, lactose, total solids and SCC). The least square means were not presented due the high number of the levels (39) and we judged be not so important. 


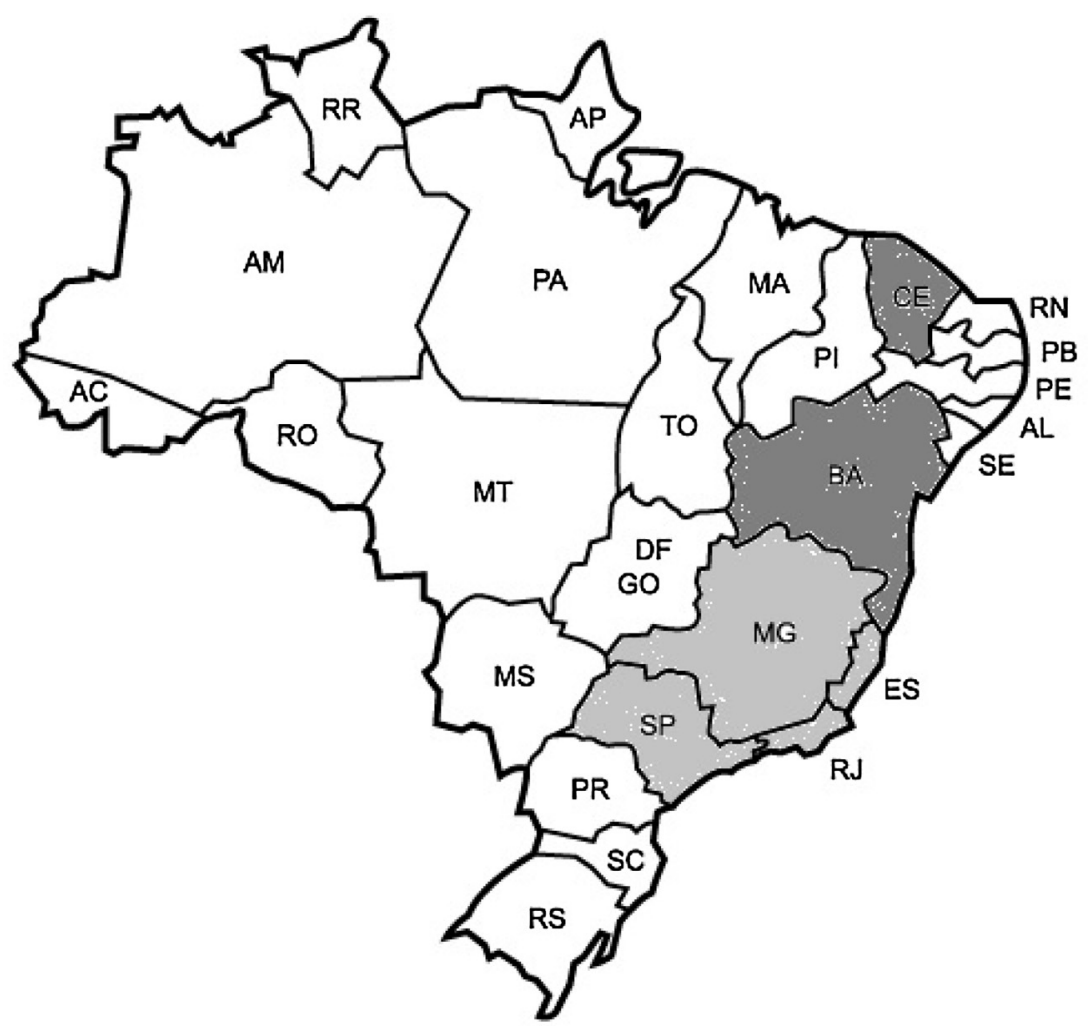

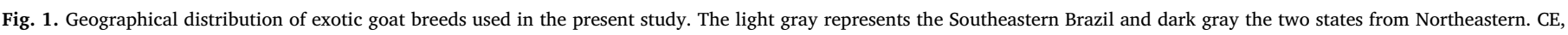
Ceará; BA, Bahia; MG, Minas Gerais, ES, Espírito Santo; RJ, Rio de Janeiro; SP, São Paulo.

\section{Discussion}

This study is the first work of characterization of exotic breeds in tropical climate with a database derived of official milk recording. It demonstrates that the traits related to the production of milk of imported goats breeds in tropical climate: MY, LY305, LL and DMY are influenced by the genetic of the animal (breed) and by the environmental conditions, such as flock, month and year of production. DL in the Saanen breed has a positive correlation with MY $\left(r_{g}=0.91\right.$; unpublished data from Capragene ${ }^{\circ}$ ) and LY305 $\left(\mathrm{r}_{\mathrm{g}}=0.87\right.$; unpublished data from Capragene ${ }^{\circ}$ ) and this implies that selection for increased milk yield will increase the lactation duration. In this same breed, heritabilities of 0.20 for MY, 0.07 for LL, 0.21 for LY305 and 0.23 for DMY were estimated (unpublished data from Capragene") which indicate some potential to direct selection of the does. Milk composition and SCC are influenced by genetic of animal, ambient conditions and also by physiological stages of the does (lactation and test-day milk order). In the Saanen breed, $18 \%, 11 \%, 10 \%, 0.6 \%$ and $10 \%$ (unpublished data from Capragene ${ }^{\circ}$ ) of the total variation of the traits fat, PRO, TS, LAC and SCC, respectively, correspond to the average effects of the genes. We did not present genetic parameters for the other breeds because the available amount of data is yet so small to this kind of analysis, since Saanen breed is the most numerous in the country. In 2014, the first Brazilian Dairy Buck Directory was released (Facó et al., 2014). The average genetic gain for LY305 after the implementation of the progeny testing (2005-2013) was $4.54 \mathrm{~kg}$ /year (Facó et al., 2014). Genomic Predicted Transmitting Abilities (genomic PTA) analyzes are currently being realized for Saanen breed, with the first genomic PTA directory planned for July 2016.

The breeds were similar in terms of milk production in conditions of management of the Southeastern Brazil probably because they went through the same selection process. The lower total milk production and lactation length of Anglo Nubian breed (from Northeast) in relation to those of Southeastern breeds, including the Saanen breed, were expected. But, the Anglo Nubian and Saanen raised in Northeast did not differ. Despite the averages have been corrected for the effects of flock within breed, it is possible that there still was some confounding between the genetic potential of breed and the region which it was not possible to separate in the analyses. Must be highlighted there were no any time by region interactions in the data.

The milk production and the lactation length of Saanen breed reared in Southeast differed considerably from those of the animals raised in the Northeast, despite there was some genetic connectedness between the herds in this two regions. This indicates that, as evidenced by Lopes (2011), there is a positive relationship between the milk yield per doe and the climate variables, such as relative humidity, normalized difference vegetative index (quantitative and qualitative assessment of the stage of vegetation from satellite images) and rainfall. According to this author, the milk production was positively correlated with the level of quality of the grazing in the farms and the human development index (HDI) of the region. Thus, the higher levels of income, education of farmers and environmental conditions, greater will be the milk production. The Southeast region has the highest HDI in Brazil while the Northeast region has HDI below the average of the country. These regions have, on average, low and high annual temperatures, respectively. Indeed, stressful environmental conditions negatively affect the milk production and the fertility of the animals, mainly by influence in the food intake. According to Salama et al. (2014), at the same time that heat stress reduces the food intake, also increases maintenance requirements needed for additional activities such as those required for maintenance and homeothermy (muscle movements panting, sweating). It also promotes increased chemical reactions in the body and the production of heat shock proteins, which consume large amounts of adenosine triphosphate molecules. Those authors also reported that the increase of additional requirements is around 30\%, thus the energy intake is not sufficient to produce milk. These aspects related to climate are often limiting to the milk production in tropical regions, especially for semi-arid climates, such as the case of the Brazilian Northeast. 
Table 1

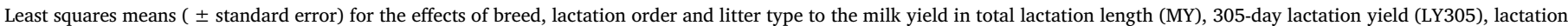
length (LL), daily milk yield (DMY) for dairy goats in Brazil.

\begin{tabular}{|c|c|c|c|c|}
\hline Effect/Level & MY (kg) & LY305 (kg) & LL (days) & DMY (kg/day) \\
\hline $\mathrm{N}$ & 3,888 & 3,888 & 3,888 & 3,888 \\
\hline Overall & $853.64 \pm 450.58$ & $716.98 \pm 259.55$ & $310.15 \pm 112.37$ & $2.61 \pm 0.71$ \\
\hline $\mathrm{CV} \%$ & 52.78 & 36.20 & 36.23 & 27.30 \\
\hline Breed & $* *$ & $* *$ & $* *$ & $* *$ \\
\hline Alpine & $820.69 \pm 81.57^{\mathrm{a}}$ & $754.95 \pm 46.99^{\mathrm{a}}$ & $264.55 \pm 20.34^{\mathrm{ab}}$ & $2.97 \pm 0.13^{\mathrm{a}}$ \\
\hline Anglo Nubian & $339.94 \pm 121.25^{\mathrm{b}}$ & $331.59 \pm 69.84^{b}$ & $265.34 \pm 30.24^{\mathrm{ab}}$ & $1.35 \pm 0.19^{b}$ \\
\hline Saanen S & $940.38 \pm 30.06^{\mathrm{a}}$ & $817.31 \pm 17.32^{\mathrm{a}}$ & $287.43 \pm 7.50^{\mathrm{a}}$ & $3.13 \pm 0.05^{\mathrm{a}}$ \\
\hline Saanen N & $362.05 \pm 21.28^{\mathrm{b}}$ & $372.19 \pm 12.26^{\mathrm{b}}$ & $241.78 \pm 5.31^{b}$ & $1.56 \pm 0.03^{\mathrm{b}}$ \\
\hline Toggenburg & $696.56 \pm 143.41^{\mathrm{ab}}$ & $638.63 \pm 82.61^{a}$ & $267.65 \pm 35.76^{\mathrm{ab}}$ & $2.57 \pm 0.23^{\mathrm{a}}$ \\
\hline Lactation order & $* *$ & $* *$ & $* *$ & $* *$ \\
\hline 1 & $683.32 \pm 43.02^{\mathrm{ab}}$ & $580.54 \pm 24.78^{b}$ & $291.02 \pm 10.73^{\mathrm{a}}$ & $2.24 \pm 0.07^{b}$ \\
\hline 2 & $712.10 \pm 44.52^{\mathrm{a}}$ & $629.16 \pm 25.64^{\mathrm{a}}$ & $280.49 \pm 11.10^{\mathrm{ab}}$ & $2.42 \pm 0.07^{\mathrm{a}}$ \\
\hline 3 & $646.74 \pm 46.78^{\mathrm{ab}}$ & $613.61 \pm 26.95^{\mathrm{ab}}$ & $266.41 \pm 11.67^{\mathrm{bc}}$ & $2.39 \pm 0.07^{\mathrm{ab}}$ \\
\hline 4 & $625.09 \pm 49.38^{\mathrm{ab}}$ & $604.94 \pm 28.44^{\mathrm{ab}}$ & $262.76 \pm 12.31^{\mathrm{bc}}$ & $2.37 \pm 0.08^{\mathrm{ab}}$ \\
\hline 5 & $583.82 \pm 53.73^{\mathrm{b}}$ & $557.57 \pm 30.95^{\mathrm{b}}$ & $251.01 \pm 13.40^{\mathrm{c}}$ & $2.33 \pm 0.08^{\mathrm{ab}}$ \\
\hline 6 & $606.47 \pm 60.59^{\mathrm{ab}}$ & $561.77 \pm 34.90^{\mathrm{b}}$ & $267.47 \pm 15.11^{\mathrm{ab}}$ & $2.21 \pm 0.09^{b}$ \\
\hline 7 & $565.93 \pm 73.40^{b}$ & $532.96 \pm 42.28^{b}$ & $238.31 \pm 18.31^{\mathrm{c}}$ & $2.24 \pm 0.12^{b}$ \\
\hline Litter type & n.s & $* *$ & n.s & $* *$ \\
\hline $\mathrm{FF}$ & $654.72 \pm 47.59$ & $586.50 \pm 27.41^{\mathrm{ab}}$ & $270.94 \pm 11.87$ & $2.34 \pm 0.07^{\mathrm{ab}}$ \\
\hline $\mathrm{F}$ & $583.70 \pm 45.65$ & $560.12 \pm 26.30^{\mathrm{ab}}$ & $259.75 \pm 11.38$ & $2.24 \pm 0.07^{\mathrm{bc}}$ \\
\hline MF & $644.76 \pm 45.30$ & $592.20 \pm 26.10^{\mathrm{a}}$ & $266.46 \pm 11.30$ & $2.33 \pm 0.07^{\mathrm{ab}}$ \\
\hline MM & $654.10 \pm 47.76$ & $592.87 \pm 27.51^{\mathrm{ab}}$ & $269.13 \pm 11.91$ & $2.35 \pm 0.07^{\mathrm{ab}}$ \\
\hline M & $589.68 \pm 45.15$ & $552.37 \pm 26.01^{\mathrm{b}}$ & $264.42 \pm 11.26$ & $2.20 \pm 0.07^{c}$ \\
\hline Others & $664.58 \pm 52.90$ & $613.56 \pm 30.47^{\mathrm{a}}$ & $261.41 \pm 13.19$ & $2.43 \pm 0.08^{\mathrm{a}}$ \\
\hline
\end{tabular}

$* *=\mathrm{P}<0.01$. n.s $=\mathrm{P}>0.05$.

$\mathrm{CV}=$ coefficient of variation.

a,ab,b.. Averages with the same letters in the same column within the same effect did not differ statistically by the Tukey-Kramer test (P $>0.05)$.

$\mathrm{F}=$ one female.

$\mathrm{FF}=$ two female.

$\mathrm{MF}=$ one male and female.

$\mathrm{M}=$ one male.

$\mathrm{MM}=$ two male.

Saanen $\mathrm{S}=$ Saanen reared in Southeastern Brazil.

Saanen N = Saanen reared in Northeastern Brazil.

Table 2

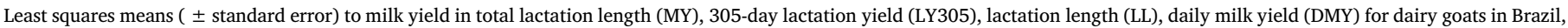
according to the month of the year.

\begin{tabular}{|c|c|c|c|c|}
\hline Month & MY (kg) & LY305 (kg) & LL (days) & DMY (kg/day) \\
\hline 1 & $642.42 \pm 57.42^{\mathrm{ab}}$ & $571.16 \pm 33.08^{\mathrm{ab}}$ & $274.13 \pm 14.32^{\mathrm{ab}}$ & $2.28 \pm 0.09$ \\
\hline 2 & $604.82 \pm 54.97^{\mathrm{ab}}$ & $560.78 \pm 31.67^{\mathrm{ab}}$ & $254.75 \pm 13.71^{\mathrm{abc}}$ & $2.32 \pm 0.09$ \\
\hline 3 & $645.99 \pm 48.03^{\mathrm{a}}$ & $581.69 \pm 27.67^{\mathrm{ab}}$ & $261.76 \pm 11.98^{\mathrm{ab}}$ & $2.34 \pm 0.08$ \\
\hline 4 & $657.94 \pm 49.49^{\mathrm{a}}$ & $599.40 \pm 28.51^{\mathrm{ab}}$ & $272.03 \pm 12.34^{\mathrm{ab}}$ & $2.33 \pm 0.08$ \\
\hline 5 & $519.59 \pm 52.43^{\mathrm{b}}$ & $544.43 \pm 30.20^{\mathrm{b}}$ & $230.98 \pm 13.07^{c}$ & $2.28 \pm 0.08$ \\
\hline 6 & $688.70 \pm 53.12^{\mathrm{a}}$ & $632.40 \pm 30.60^{\mathrm{a}}$ & $293.69 \pm 13.25^{\mathrm{a}}$ & $2.27 \pm 0.08$ \\
\hline 7 & $591.06 \pm 49.33^{\mathrm{ab}}$ & $583.63 \pm 28.42^{\mathrm{ab}}$ & $251.92 \pm 12.30^{\mathrm{bc}}$ & $2.29 \pm 0.08$ \\
\hline 8 & $633.72 \pm 48.34^{\mathrm{ab}}$ & $576.67 \pm 27.85^{\mathrm{ab}}$ & $262.61 \pm 12.06^{\mathrm{ab}}$ & $2.31 \pm 0.08$ \\
\hline 9 & $664.32 \pm 48.34^{\mathrm{a}}$ & $618.35 \pm 27.85^{\mathrm{a}}$ & $264.86 \pm 12.06^{\mathrm{ab}}$ & $2.42 \pm 0.08$ \\
\hline 10 & $635.95 \pm 49.95^{\mathrm{ab}}$ & $571.44 \pm 28.77^{\mathrm{ab}}$ & $266.00 \pm 12.46^{\mathrm{ab}}$ & $2.29 \pm 0.08$ \\
\hline 11 & $643.32 \pm 52.58^{\mathrm{ab}}$ & $579.52 \pm 30.29^{\mathrm{ab}}$ & $269.68 \pm 13.11^{\mathrm{ab}}$ & $2.35 \pm 0.08$ \\
\hline 12 & $655.27 \pm 56.55^{\mathrm{ab}}$ & $575.73 \pm 32.57^{\mathrm{ab}}$ & $281.82 \pm 14.10^{\mathrm{ab}}$ & $2.29 \pm 0.09$ \\
\hline $\mathrm{N}$ & 3,888 & 3,888 & 3,888 & 3,888 \\
\hline Overall & $853.64 \pm 450.58$ & $716.98 \pm 259.55$ & $310.15 \pm 112.37$ & $2.61 \pm 0.71$ \\
\hline CV\% & 52.78 & 36.20 & 36.23 & 27.30 \\
\hline
\end{tabular}

a,ab,b.. Averages with the same letters in the same column within the same effect did not differ statistically by the Tukey-Kramer test (P $>0.05)$.

The averages for MY and DMY in the first lactation were $683.32 \pm 43.02 \mathrm{~kg}$ and $2.24 \pm 0.07 \mathrm{~kg} /$ day, respectively. In absolute terms, the average of MY was slightly larger than that reported for the first lactation of these same breeds in France before 19 years. Bélichon et al. (1998) reported means of $648 \pm 167 \mathrm{~kg}$ and $676 \pm 182 \mathrm{~kg}$ for the first lactation of Alpine and Saanen does, respectively. Boichard et al. (1989) reported averages of $447 \mathrm{~kg}$ and $490 \mathrm{~kg}$ for the first lactation of purebred does of Alpine and Saanen breeds, respectively. It is noteworthy that in both studies, these productions were adjusted for the duration of lactation. Rupp et al. (2011) estimated means of $668 \pm 158 \mathrm{~kg}$ and $698 \pm 178 \mathrm{~kg}$ to the first lactation adjusted to 250 days of Alpine and Saanen, respectively. In this last report the average for Saanen was higher than the observed in our study. In general way the highest yield for MY observed in this study is justified because it was computed for lactations longer than those adjusted up to 250 days in the aforementioned studies. Actually, the average for LL in the first lactation was $291.02 \pm 10.73$ days. Still, the small superiority of the averages in our study is not justified by the higher number of 
Table 3

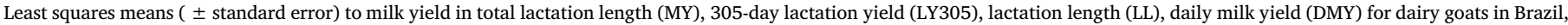
according to the year of production.

\begin{tabular}{|c|c|c|c|c|}
\hline Year & MY (kg) & LY305 (kg) & LL (days) & DMY (kg/day) \\
\hline 1998 & $506.89 \pm 84.74^{\mathrm{b}}$ & $521.09 \pm 48.82^{\mathrm{b}}$ & $234.50 \pm 21.13^{\mathrm{cd}}$ & $2.27 \pm 0.13^{\mathrm{abc}}$ \\
\hline 1999 & $616.20 \pm 66.74^{\mathrm{b}}$ & $577.12 \pm 38.44^{\mathrm{b}}$ & $234.17 \pm 16.64^{\mathrm{cd}}$ & $2.46 \pm 0.10^{\mathrm{ab}}$ \\
\hline 2000 & $577.58 \pm 62.15^{\mathrm{b}}$ & $570.78 \pm 35.80^{b}$ & $218.04 \pm 15.50^{\mathrm{d}}$ & $2.45 \pm 0.10^{\mathrm{ab}}$ \\
\hline 2001 & $599.32 \pm 60.80^{\mathrm{b}}$ & $583.03 \pm 35.02^{\mathrm{b}}$ & $236.49 \pm 15.16^{\mathrm{cd}}$ & $2.45 \pm 0.10^{\mathrm{ab}}$ \\
\hline 2002 & $689.88 \pm 67.17^{\mathrm{ab}}$ & $625.96 \pm 38.69^{\mathrm{ab}}$ & $269.27 \pm 16.75^{\mathrm{abcd}}$ & $2.38 \pm 0.11^{\mathrm{abc}}$ \\
\hline 2003 & $801.95 \pm 59.42^{\mathrm{a}}$ & $624.95 \pm 34.23^{\mathrm{ab}}$ & $308.86 \pm 14.82^{\mathrm{a}}$ & $2.37 \pm 0.09^{\mathrm{abc}}$ \\
\hline 2004 & $686.09 \pm 56.75^{\mathrm{ab}}$ & $574.31 \pm 32.69^{\mathrm{b}}$ & $268.54 \pm 14.15^{\mathrm{abcd}}$ & $2.27 \pm 0.09^{\mathrm{abc}}$ \\
\hline 2005 & $630.50 \pm 58.98^{\mathrm{ab}}$ & $600.49 \pm 33.98^{b}$ & $270.11 \pm 14.71^{\mathrm{abcd}}$ & $2.31 \pm 0.09^{\mathrm{abc}}$ \\
\hline 2006 & $603.38 \pm 63.93^{b}$ & $582.17 \pm 36.83^{b}$ & $271.95 \pm 15.94^{\mathrm{abcd}}$ & $2.26 \pm 0.10^{\mathrm{abc}}$ \\
\hline 2007 & $614.29 \pm 49.73^{\mathrm{b}}$ & $566.25 \pm 28.65^{b}$ & $291.64 \pm 12.40^{\mathrm{a}}$ & $2.17 \pm 0.08^{\mathrm{bc}}$ \\
\hline 2008 & $618.20 \pm 50.37^{\mathrm{b}}$ & $552.52 \pm 29.01^{\mathrm{b}}$ & $295.80 \pm 12.56^{\mathrm{a}}$ & $2.12 \pm 0.08^{\mathrm{c}}$ \\
\hline 2009 & $595.40 \pm 48.72^{\mathrm{b}}$ & $558.35 \pm 28.07^{\mathrm{b}}$ & $286.73 \pm 12.15^{\mathrm{ab}}$ & $2.13 \pm 0.08^{c}$ \\
\hline 2010 & $655.66 \pm 47.18^{\mathrm{ab}}$ & $617.06 \pm 27.18^{\mathrm{ab}}$ & $270.27 \pm 11.77^{\mathrm{abcd}}$ & $2.38 \pm 0.07^{\mathrm{abc}}$ \\
\hline 2011 & $782.09 \pm 47.14^{\mathrm{a}}$ & $670.97 \pm 27.16^{\mathrm{a}}$ & $298.14 \pm 11.76^{a}$ & $2.47 \pm 0.07^{\mathrm{a}}$ \\
\hline 2012 & $657.03 \pm 47.52^{\mathrm{ab}}$ & $612.00 \pm 27.38^{\mathrm{b}}$ & $273.95 \pm 11.85^{\mathrm{abc}}$ & $2.33 \pm 0.07^{\mathrm{abc}}$ \\
\hline 2013 & $522.12 \pm 53.92^{\mathrm{b}}$ & $557.22 \pm 31.06^{\mathrm{b}}$ & $251.30 \pm 13.45^{\mathrm{bcd}}$ & $2.26 \pm 0.08^{\mathrm{abc}}$ \\
\hline 2014 & $586.14 \pm 73.49^{b}$ & $515.63 \pm 42.33^{\mathrm{b}}$ & $231.22 \pm 18.33^{\mathrm{cd}}$ & $2.26 \pm 0.12^{\mathrm{abc}}$ \\
\hline $\mathrm{N}$ & 3,888 & 3,888 & 3,888 & 3,888 \\
\hline Overall & $853.64 \pm 450.58$ & $716.98 \pm 259.55$ & $310.15 \pm 112.37$ & $2.61 \pm 0.71$ \\
\hline $\mathrm{CV} \%$ & 52.78 & 36.20 & 36.23 & 27.30 \\
\hline
\end{tabular}

a,ab,b.. Averages with the same letters in the same column within the same effect did not differ statistically by the Tukey-Kramer test (P $>0.05)$.

Table 4

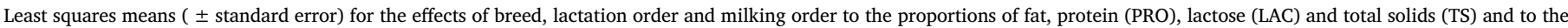
somatic cell count $(\log 10(\mathrm{SCC}))$ for dairy goats in Brazil.

\begin{tabular}{|c|c|c|c|c|c|}
\hline Effect/Level & Fat $(\%)$ & PRO (\%) & LAC (\%) & TS (\%) & $\log 10(\mathrm{SCC})($ cells $/ \mathrm{mL})$ \\
\hline $\mathrm{N}$ & 10.696 & 10.380 & 7.495 & 8.423 & 9.443 \\
\hline Overall & $3.69 \pm 0.75$ & $2.91 \pm 0.35$ & $4.23 \pm 0.27$ & $11.77 \pm 1.06$ & $5.91 \pm 0.47$ \\
\hline CV\% & 20.44 & 11.87 & 6.38 & 8.98 & 7.94 \\
\hline Breed & $* *$ & $* *$ & ns & $* *$ & $* *$ \\
\hline Alpine & $3.76 \pm 0.08^{\mathrm{b}}$ & $2.95 \pm 0.04^{\mathrm{b}}$ & $4.07 \pm 0.03$ & $11.89 \pm 0.12^{\mathrm{b}}$ & $6.06 \pm 0.06^{\mathrm{a}}$ \\
\hline Anglo Nubian & $4.25 \pm 0.11^{\mathrm{a}}$ & $3.40 \pm 0.05^{\mathrm{a}}$ & $4.15 \pm 0.04$ & $12.51 \pm 0.16^{\mathrm{a}}$ & $5.63 \pm 0.08^{b}$ \\
\hline Saanen S & $3.65 \pm 0.05^{\mathrm{b}}$ & $2.95 \pm 0.02^{\mathrm{b}}$ & $4.10 \pm 0.02$ & $11.77 \pm 0.07^{\mathrm{b}}$ & $5.98 \pm 0.05^{\mathrm{a}}$ \\
\hline Saanen N & $3.24 \pm 0.06^{c}$ & $2.59 \pm 0.03^{c}$ & $4.14 \pm 0.02$ & $11.05 \pm 0.08^{\mathrm{c}}$ & $5.55 \pm 0.05^{b}$ \\
\hline Toggenburg & $3.35 \pm 0.07^{c}$ & $2.87 \pm 0.03^{b}$ & $4.07 \pm 0.03$ & $11.32 \pm 0.15^{c}$ & $6.00 \pm 0.07^{\mathrm{a}}$ \\
\hline Lactation order & $* *$ & $* *$ & $* *$ & $* *$ & $* *$ \\
\hline 1 & $3.66 \pm 0.05^{\mathrm{ab}}$ & $2.98 \pm 0.02^{\mathrm{ab}}$ & $4.13 \pm 0.02^{\mathrm{a}}$ & $11.79 \pm 0.07^{\mathrm{ab}}$ & $5.68 \pm 0.04^{c}$ \\
\hline 2 & $3.57 \pm 0.05^{c}$ & $2.96 \pm 0.02^{\mathrm{b}}$ & $4.10 \pm 0.02^{b}$ & $11.63 \pm 0.07^{c}$ & $5.74 \pm 0.04^{b}$ \\
\hline 3 & $3.62 \pm 0.05^{\mathrm{bc}}$ & $2.96 \pm 0.03^{\mathrm{b}}$ & $4.08 \pm 0.02^{b}$ & $11.65 \pm 0.08^{\mathrm{c}}$ & $5.84 \pm 0.05^{\mathrm{a}}$ \\
\hline 4 & $3.62 \pm 0.06^{\mathrm{bc}}$ & $2.89 \pm 0.03^{\mathrm{c}}$ & $4.09 \pm 0.02^{\mathrm{b}}$ & $11.63 \pm 0.08^{\mathrm{c}}$ & $5.85 \pm 0.05^{\mathrm{a}}$ \\
\hline 5 & $3.61 \pm 0.06^{\mathrm{bc}}$ & $2.95 \pm 0.03^{b}$ & $4.12 \pm 0.03^{\mathrm{ab}}$ & $11.69 \pm 0.10^{\mathrm{bc}}$ & $5.90 \pm 0.05^{\mathrm{a}}$ \\
\hline 6 & $3.85 \pm 0.08^{\mathrm{a}}$ & $3.08 \pm 0.04^{\mathrm{a}}$ & $4.12 \pm 0.03^{\mathrm{ab}}$ & $12.08 \pm 0.13^{\mathrm{a}}$ & $5.94 \pm 0.06^{\mathrm{a}}$ \\
\hline 7 & $3.62 \pm 0.10^{\mathrm{bc}}$ & $2.85 \pm 0.05^{c}$ & $4.07 \pm 0.04^{\mathrm{b}}$ & $11.48 \pm 0.18^{\mathrm{c}}$ & $5.96 \pm 0.07^{\mathrm{a}}$ \\
\hline Number of daily milking & $* *$ & $* *$ & $* *$ & $* *$ & $* *$ \\
\hline 1 & $3.84 \pm 0.05^{\mathrm{a}}$ & $3.01 \pm 0.02^{\mathrm{a}}$ & $4.04 \pm 0.02^{b}$ & $11.92 \pm 0.08^{\mathrm{a}}$ & $5.96 \pm 0.04^{\mathrm{a}}$ \\
\hline 2 & $3.46 \pm 0.06^{\mathrm{b}}$ & $2.90 \pm 0.03^{\mathrm{b}}$ & $4.16 \pm 0.02^{\mathrm{a}}$ & $11.49 \pm 0.09^{\mathrm{b}}$ & $5.73 \pm 0.05^{\mathrm{b}}$ \\
\hline
\end{tabular}

$* *=\mathrm{P}<0.01$. n.s $=\mathrm{P}>0.05$.

$\mathrm{CV}=$ coefficient of variation.

a,ab,b.. Averages with the same letters in the same column within the same effect did not differ statistically by the Tukey-Kramer test (P $>0.05)$.

Saanen S = Saanen reared in Southeastern Brazil.

Saanen $\mathrm{N}=$ Saanen reared in Northeastern Brazil.

days in milk which demonstrates the superior potential of the French animals.

The averages figures for MY of Saanen goats in South Africa (Olivier et al., 2005) and Mexico (Torres-Vázquez et al., 2010) were $841.1 \mathrm{~kg}$ (average of 246 days in milk) and $933 \mathrm{~kg}$ (adjusted for 305 days in milk), respectively. These averages are close to those of our study for Saanen goats reared in Southeast region, and higher than those reared in Northeast region. Actually, the climate of the regions of these studies is more similar to the Brazil Southeast, in contrary of the semi-arid and hot weather of Northeast region.

According to Lobo and Lobo (2015), the differences in the levels of production may be related both to the individual genetic potential of the animal of the flocks, as well as by the differences in feeding management, facilities, food and climate and socioeconomic conditions across the regions. The breeds raised in Southeast region (Saanen, Toggenburg and Alpine), despite were managed on similar conditions, presented differences on genetic potential for milk composition only for fat and total solids percentages, with superiority of Alpine and Saanen in relation to Toggenburg. Already in the Northeast region, the Anglo Nubian breed exceeded the Saanen breed for fat, protein and total solids percentages. The Anglo Nubian had higher averages for these traits also in relation of Saanen animals raised in Southeast region. It is important to highlight that there was genetic connectedness among the does of Saanen breed managed in the two regions. Thus, this superiority of the Anglo Nubian breed must be result of its lower milk yield, since milk yield and composition percentages are negatively correlated (Oliveira 
Table 5

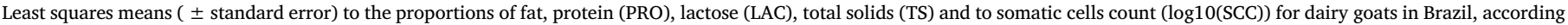
to the test-day milk order.

\begin{tabular}{|c|c|c|c|c|c|}
\hline Order & Fat $(\%)$ & PRO (\%) & LAC (\%) & TS (\%) & $\log 10(\mathrm{SCC})($ cells $/ \mathrm{mL})$ \\
\hline 1 & $3.93 \pm 0.04^{\mathrm{a}}$ & $2.94 \pm 0.02$ & $4.40 \pm 0.02^{\mathrm{a}}$ & $12.24 \pm 0.07^{\mathrm{a}}$ & $5.61 \pm 0.04^{\mathrm{b}}$ \\
\hline 2 & $3.57 \pm 0.04^{\mathrm{ab}}$ & $2.81 \pm 0.02$ & $4.24 \pm 0.02^{\mathrm{ab}}$ & $11.57 \pm 0.07^{\mathrm{b}}$ & $5.70 \pm 0.04^{\mathrm{ab}}$ \\
\hline 3 & $3.55 \pm 0.04^{\mathrm{ab}}$ & $2.84 \pm 0.02$ & $4.16 \pm 0.02^{\mathrm{abc}}$ & $11.53 \pm 0.07^{\mathrm{b}}$ & $5.76 \pm 0.04^{\mathrm{ab}}$ \\
\hline 4 & $3.58 \pm 0.04^{\mathrm{ab}}$ & $2.87 \pm 0.02$ & $4.13 \pm 0.02^{\mathrm{c}}$ & $11.56 \pm 0.07^{\mathrm{b}}$ & $5.77 \pm 0.04^{\mathrm{ab}}$ \\
\hline 5 & $3.65 \pm 0.04^{\mathrm{ab}}$ & $2.93 \pm 0.02$ & $4.13 \pm 0.02^{c}$ & $11.66 \pm 0.07^{\mathrm{b}}$ & $5.82 \pm 0.04^{\mathrm{ab}}$ \\
\hline 6 & $3.60 \pm 0.05^{\mathrm{ab}}$ & $2.96 \pm 0.02$ & $4.13 \pm 0.02^{c}$ & $11.72 \pm 0.07^{\mathrm{b}}$ & $5.79 \pm 0.04^{\mathrm{ab}}$ \\
\hline 7 & $3.66 \pm 0.05^{\mathrm{ab}}$ & $2.98 \pm 0.02$ & $4.11 \pm 0.02^{\mathrm{c}}$ & $11.76 \pm 0.07^{\mathrm{b}}$ & $5.83 \pm 0.04^{\mathrm{ab}}$ \\
\hline 8 & $3.71 \pm 0.05^{\mathrm{ab}}$ & $2.99 \pm 0.02$ & $4.10 \pm 0.02^{c}$ & $11.76 \pm 0.08^{\mathrm{b}}$ & $5.88 \pm 0.05^{\mathrm{ab}}$ \\
\hline 9 & $3.71 \pm 0.06^{\mathrm{ab}}$ & $3.00 \pm 0.02$ & $4.11 \pm 0.02^{c}$ & $11.83 \pm 0.09^{b}$ & $5.90 \pm 0.05^{\mathrm{ab}}$ \\
\hline 10 & $3.72 \pm 0.06^{\mathrm{ab}}$ & $3.01 \pm 0.02$ & $4.08 \pm 0.02^{c}$ & $11.83 \pm 0.09^{\mathrm{b}}$ & $5.92 \pm 0.05^{\mathrm{ab}}$ \\
\hline 11 & $3.85 \pm 0.07^{\mathrm{ab}}$ & $2.99 \pm 0.03$ & $4.12 \pm 0.03^{c}$ & $11.97 \pm 0.09^{\mathrm{ab}}$ & $5.86 \pm 0.05^{\mathrm{ab}}$ \\
\hline 12 & $3.77 \pm 0.08^{\mathrm{ab}}$ & $3.02 \pm 0.03$ & $4.10 \pm 0.03^{c}$ & $11.85 \pm 0.10^{\mathrm{b}}$ & $5.81 \pm 0.06^{\mathrm{ab}}$ \\
\hline 13 & $3.59 \pm 0.09^{\mathrm{ab}}$ & $2.97 \pm 0.04$ & $4.11 \pm 0.03^{c}$ & $11.73 \pm 0.11^{\mathrm{b}}$ & $5.60 \pm 0.06^{\mathrm{b}}$ \\
\hline 14 & $3.64 \pm 0.09^{\mathrm{ab}}$ & $3.01 \pm 0.04$ & $4.07 \pm 0.04^{c}$ & $11.69 \pm 0.13^{\mathrm{b}}$ & $5.82 \pm 0.07^{\mathrm{ab}}$ \\
\hline 15 & $3.55 \pm 0.12^{\mathrm{ab}}$ & $2.94 \pm 0.05$ & $4.12 \pm 0.04^{\mathrm{c}}$ & $11.49 \pm 0.13^{\mathrm{b}}$ & $5.90 \pm 0.08^{\mathrm{ab}}$ \\
\hline 16 & $3.56 \pm 0.12^{\mathrm{ab}}$ & $2.96 \pm 0.06$ & $4.14 \pm 0.05^{\mathrm{bc}}$ & $11.65 \pm 0.17^{\mathrm{b}}$ & $5.71 \pm 0.08^{\mathrm{ab}}$ \\
\hline 17 & $3.52 \pm 0.13^{\mathrm{ab}}$ & $3.00 \pm 0.06$ & $4.08 \pm 0.05^{c}$ & $11.68 \pm 0.19^{\mathrm{b}}$ & $5.72 \pm 0.09^{\mathrm{ab}}$ \\
\hline 18 & $3.88 \pm 0.17^{\mathrm{ab}}$ & $3.02 \pm 0.08$ & $3.96 \pm 0.06^{\mathrm{c}}$ & $11.89 \pm 0.25^{\mathrm{ab}}$ & $6.00 \pm 0.11^{\mathrm{ab}}$ \\
\hline 19 & $3.02 \pm 0.23^{\mathrm{b}}$ & $2.90 \pm 0.11$ & $4.15 \pm 0.09^{\mathrm{abc}}$ & $11.09 \pm 0.33^{\mathrm{b}}$ & $5.90 \pm 0.15^{\mathrm{ab}}$ \\
\hline 20 & $3.51 \pm 0.27^{\mathrm{ab}}$ & $3.06 \pm 0.12$ & $3.86 \pm 0.11^{\mathrm{c}}$ & $11.47 \pm 0.41^{\mathrm{b}}$ & $5.98 \pm 0.18^{\mathrm{ab}}$ \\
\hline 21 & $4.18 \pm 0.23^{\mathrm{a}}$ & $3.08 \pm 0.10$ & $3.82 \pm 0.09^{c}$ & $12.12 \pm 0.32^{\mathrm{ab}}$ & $6.18 \pm 0.14^{\mathrm{a}}$ \\
\hline 22 & $3.69 \pm 0.44^{\mathrm{ab}}$ & $2.87 \pm 0.20$ & $4.18 \pm 0.16^{\mathrm{abc}}$ & $11.79 \pm 0.62^{\mathrm{b}}$ & $5.94 \pm 0.27^{\mathrm{ab}}$ \\
\hline 23 & $3.52 \pm 0.31^{\mathrm{ab}}$ & $2.74 \pm 0.14$ & $4.07 \pm 0.11^{c}$ & $11.35 \pm 0.44^{\mathrm{b}}$ & $6.02 \pm 0.20^{\mathrm{ab}}$ \\
\hline $\mathrm{N}$ & 10.696 & 10.380 & 7.495 & 8.423 & 9.443 \\
\hline Overall & $3.69 \pm 0.75$ & $2.91 \pm 0.35$ & $4.23 \pm 0.27$ & $11.77 \pm 1.06$ & $5.91 \pm 0.47$ \\
\hline $\mathrm{CV} \%$ & 20.44 & 11.87 & 6.38 & 8.98 & 7.94 \\
\hline
\end{tabular}

a,ab,b..Averages with the same letters in the same column within the same effect did not differ statistically by the Tukey-Kramer test (P $>0.05$ ).

Table 6

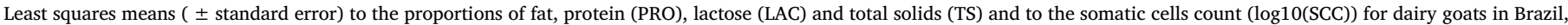
according to month of recording.

\begin{tabular}{|c|c|c|c|c|c|}
\hline Month & Fat (\%) & PRO (\%) & LAC (\%) & TS (\%) & $\log 10(\mathrm{SCC})($ cells $/ \mathrm{mL})$ \\
\hline 1 & $3.51 \pm 0.06^{\mathrm{ef}}$ & $2.81 \pm 0.03^{\mathrm{d}}$ & $4.03 \pm 0.02^{\mathrm{d}}$ & $11.30 \pm 0.08^{g}$ & $5.84 \pm 0.05^{\mathrm{ab}}$ \\
\hline 2 & $3.47 \pm 0.06^{f}$ & $2.83 \pm 0.03^{\mathrm{d}}$ & $4.11 \pm 0.02^{\mathrm{bc}}$ & $11.36 \pm 0.09^{g}$ & $5.85 \pm 0.05^{\mathrm{ab}}$ \\
\hline 3 & $3.63 \pm 0.06^{\mathrm{cd}}$ & $2.93 \pm 0.03^{c}$ & $4.06 \pm 0.02^{\mathrm{cd}}$ & $11.68 \pm 0.09^{\mathrm{de}}$ & $5.88 \pm 0.05^{\mathrm{a}}$ \\
\hline 4 & $3.72 \pm 0.06^{\mathrm{bc}}$ & $3.00 \pm 0.03^{\mathrm{b}}$ & $4.11 \pm 0.02^{\mathrm{bc}}$ & $11.79 \pm 0.08^{\mathrm{bcd}}$ & $5.91 \pm 0.05^{\mathrm{a}}$ \\
\hline 5 & $3.86 \pm 0.06^{\mathrm{a}}$ & $3.05 \pm 0.03^{\mathrm{ab}}$ & $4.12 \pm 0.02^{\mathrm{abc}}$ & $12.05 \pm 0.09^{\mathrm{a}}$ & $5.88 \pm 0.05^{\mathrm{a}}$ \\
\hline 6 & $3.87 \pm 0.06^{\mathrm{a}}$ & $3.07 \pm 0.03^{\mathrm{a}}$ & $4.11 \pm 0.02^{\mathrm{bc}}$ & $12.06 \pm 0.08^{\mathrm{a}}$ & $5.87 \pm 0.05^{\mathrm{ab}}$ \\
\hline 7 & $3.80 \pm 0.06^{\mathrm{ab}}$ & $3.03 \pm 0.03^{\mathrm{ab}}$ & $4.15 \pm 0.02^{\mathrm{ab}}$ & $11.93 \pm 0.09^{\mathrm{abc}}$ & $5.84 \pm 0.05^{\mathrm{ab}}$ \\
\hline 8 & $3.68 \pm 0.06^{\mathrm{bcd}}$ & $3.00 \pm 0.03^{b}$ & $4.16 \pm 0.02^{\mathrm{a}}$ & $11.93 \pm 0.09^{\mathrm{ab}}$ & $5.74 \pm 0.05^{c}$ \\
\hline 9 & $3.62 \pm 0.06^{\text {cde }}$ & $3.00 \pm 0.03^{\mathrm{b}}$ & $4.11 \pm 0.02^{\mathrm{abc}}$ & $11.71 \pm 0.09^{\text {cde }}$ & $5.85 \pm 0.05^{\mathrm{ab}}$ \\
\hline 10 & $3.63 \pm 0.06^{\mathrm{cd}}$ & $2.91 \pm 0.03^{c}$ & $4.08 \pm 0.02^{c}$ & $11.65 \pm 0.08^{\mathrm{def}}$ & $5.80 \pm 0.05^{\mathrm{bc}}$ \\
\hline 11 & $3.57 \pm 0.06^{\text {def }}$ & $2.90 \pm 0.03^{c}$ & $4.10 \pm 0.02^{\mathrm{bc}}$ & $11.56 \pm 0.08^{\mathrm{ef}}$ & $5.85 \pm 0.05^{\mathrm{ab}}$ \\
\hline 12 & $3.47 \pm 0.06^{\mathrm{f}}$ & $2.89 \pm 0.03^{\mathrm{c}}$ & $4.08 \pm 0.02^{\mathrm{c}}$ & $11.45 \pm 0.09^{\mathrm{fg}}$ & $5.84 \pm 0.05^{\mathrm{ab}}$ \\
\hline $\mathrm{N}$ & 10.696 & 10.380 & 7.495 & 8.423 & 9.443 \\
\hline Overall & $3.69 \pm 0.75$ & $2.91 \pm 0.35$ & $4.23 \pm 0.27$ & $11.77 \pm 1.06$ & $5.91 \pm 0.47$ \\
\hline $\mathrm{CV} \%$ & 20.44 & 11.87 & 6.38 & 8.98 & 7.94 \\
\hline
\end{tabular}

a,ab,b..Averages with the same letters in the same column within the same effect did not differ statistically by the Tukey-Kramer test (P $>0.05$ ).

et al., 2016). On the other hand, the differences among the Saanen breed in the two regions must be result of a genotype $\mathrm{x}$ environment interaction. It is known that the diet may change the synthesis of milk composition, mainly the fat percentage because its synthesis is a dynamic process influenced by the amount of concentrate used in the feed. Ribeiro et al. (2008) demonstrated that the DMY and the proportion of total solids in the milk of Saanen goats reared in the South region of Brazil were higher in those animals fed with alfalfa hay than those fed with corn silage or oat hay, probably due to the higher levels of crude protein in the diet and the changes in the consume of dry matter modulated by the forage source.

Actually, the goat milk yield and composition is significantly influenced by diet, breed, stage of lactation, number of lactations, month of sampling, flock and season. The effect of lactation order observed here (Tables 1 and 4) was expected since there is a trend to growing milk yield and milk composition with the maturity of does and consequent decrease on later ages, related to better udder development and growth in size of the animal (Ishag et al., 2012). Does kidded multiple birth produced more milk (Table 1) in function of hormonal stimulus deriving of multiple fetus, explained by the levels of the hormone placental lactogen, progesterone and prolactin during gestation, which are mammary gland stimulants. The oscillation in the production (milk yield and composition) among the months and years (Tables 2, 3, 6 and 7) was expected and reflects the seasonal effects incurred from the variability in climatic conditions, flock composition and fluctuations in the availability of nutrients over the time (Ishag et al., 2012), beyond the management alterations (administrative changes, etc). The higher values of milk yield and composition in the middle months of the year are related to the winter season in Brazil, with milder weather and increased food availability. The variation in the percentages of fat, lactose and total solid (Table 5) in function of the test-day milk order is related to genetic (standard of the lactation curve 
Table 7

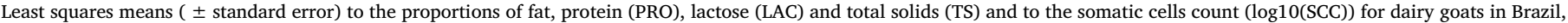
according to the year of recording.

\begin{tabular}{|c|c|c|c|c|c|}
\hline Year & Fat $(\%)$ & PRO (\%) & LAC (\%) & TS (\%) & Log10(SCC) (cells/mL) \\
\hline 1998 & $3.12 \pm 0.07^{\mathrm{h}}$ & $2.85 \pm 0.03^{\mathrm{fgh}}$ & - & - & - \\
\hline 1999 & $3.09 \pm 0.28^{\mathrm{h}}$ & $2.84 \pm 0.13^{\mathrm{fgh}}$ & - & - & - \\
\hline 2000 & $3.40 \pm 0.07^{g}$ & $2.88 \pm 0.03^{\mathrm{fgh}}$ & - & - & - \\
\hline 2001 & $3.41 \pm 0.07^{g}$ & $2.88 \pm 0.03^{\mathrm{efgh}}$ & - & - & - \\
\hline 2002 & $4.06 \pm 0.09^{\mathrm{ab}}$ & $2.91 \pm 0.05^{\text {defgh }}$ & - & $11.96 \pm 0.16^{\mathrm{ab}}$ & $5.64 \pm 0.07^{\mathrm{e}}$ \\
\hline 2003 & $4.03 \pm 0.07^{\mathrm{ab}}$ & $2.81 \pm 0.03^{\mathrm{h}}$ & - & $12.05 \pm 0.10^{\mathrm{a}}$ & $5.66 \pm 0.04^{\mathrm{e}}$ \\
\hline 2004 & $4.07 \pm 0.07^{\mathrm{a}}$ & $2.94 \pm 0.03^{\text {defg }}$ & - & $12.12 \pm 0.12^{\mathrm{a}}$ & $5.87 \pm 0.05^{\mathrm{cd}}$ \\
\hline 2005 & $3.83 \pm 0.04^{\mathrm{bcd}}$ & $2.84 \pm 0.03^{\mathrm{gh}}$ & - & $11.43 \pm 0.12^{\mathrm{cd}}$ & $5.88 \pm 0.05^{\mathrm{cd}}$ \\
\hline 2006 & $3.77 \pm 0.07^{\text {cde }}$ & $2.96 \pm 0.03^{\mathrm{def}}$ & $4.13 \pm 0.04^{\mathrm{ab}}$ & $11.59 \pm 0.12^{\mathrm{bcd}}$ & $5.81 \pm 0.05^{\mathrm{d}}$ \\
\hline 2007 & $3.71 \pm 0.06^{\mathrm{de}}$ & $2.98 \pm 0.03^{\text {cde }}$ & $4.15 \pm 0.02^{\mathrm{a}}$ & $11.67 \pm 0.09^{\mathrm{bc}}$ & $6.00 \pm 0.04^{\mathrm{bc}}$ \\
\hline 2008 & $3.85 \pm 0.05^{\mathrm{abc}}$ & $2.98 \pm 0.02^{\mathrm{de}}$ & $4.05 \pm 0.02^{\mathrm{b}}$ & $11.65 \pm 0.08^{b c}$ & $5.81 \pm 0.03^{d}$ \\
\hline 2009 & $3.95 \pm 0.05^{\mathrm{abc}}$ & $2.99 \pm 0.02^{\text {cde }}$ & $4.03 \pm 0.02^{\mathrm{b}}$ & $11.83 \pm 0.09^{\mathrm{ab}}$ & $6.07 \pm 0.04^{\mathrm{ab}}$ \\
\hline 2010 & $3.80 \pm 0.05^{\mathrm{bcd}}$ & $3.04 \pm 0.02^{\mathrm{bc}}$ & $4.22 \pm 0.02^{\mathrm{a}}$ & $11.88 \pm 0.08^{\mathrm{ab}}$ & $6.00 \pm 0.03^{b c}$ \\
\hline 2011 & $3.60 \pm 0.05^{\mathrm{ef}}$ & $3.10 \pm 0.02^{\mathrm{a}}$ & $4.15 \pm 0.02^{\mathrm{a}}$ & $11.68 \pm 0.08^{\mathrm{b}}$ & $6.07 \pm 0.03^{\mathrm{ab}}$ \\
\hline 2012 & $3.41 \pm 0.06^{\mathrm{g}}$ & $3.09 \pm 0.03^{\mathrm{ab}}$ & $4.08 \pm 0.02^{\mathrm{b}}$ & $11.41 \pm 0.09^{\mathrm{d}}$ & $6.13 \pm 0.04^{\mathrm{a}}$ \\
\hline 2013 & $3.48 \pm 0.05^{g}$ & $3.07 \pm 0.02^{\mathrm{ab}}$ & $4.06 \pm 0.02^{b}$ & $11.47 \pm 0.08^{\mathrm{bcd}}$ & $6.13 \pm 0.03^{\mathrm{a}}$ \\
\hline 2014 & $3.48 \pm 0.06^{\mathrm{fg}}$ & $3.03 \pm 0.03^{\mathrm{bcd}}$ & $4.05 \pm 0.02^{b}$ & $11.44 \pm 0.09^{\mathrm{cd}}$ & $6.08 \pm 0.04^{\mathrm{ab}}$ \\
\hline $\mathrm{N}$ & 10.696 & 10.380 & 7.495 & 8.423 & 9.443 \\
\hline Overall & $3.69 \pm 0.75$ & $2.91 \pm 0.35$ & $4.23 \pm 0.27$ & $11.77 \pm 1.06$ & $5.91 \pm 0.47$ \\
\hline $\mathrm{CV} \%$ & 20.44 & 11.87 & 6.38 & 8.98 & 7.94 \\
\hline
\end{tabular}

a,ab,b.. Averages with the same letters in the same column within the same effect did not differ statistically by the Tukey-Kramer test (P $>0.05)$.

according to breed) and non-genetic factors (differences in nutrition, climate, etc. during the lactation).

With samples collected in bulk milk tank from 13 flocks with Saanen, Toggenburg and Alpine breeds, during two lactations (August/ 2000-May/2001 and August/2001-May/2002), Souza et al. (2009) identified that the season (in Southeastern Brazil) is responsible for high variability in protein (16\%), lactose (27\%) and total solids (39\%), while the effect of flock was responsible for $27 \%$ of the variation of milk fat. Those authors observed a higher percentage of fat, lactose and total solids in the winter and lowest percentage in the summer. They also noted that in the autumn there was a higher protein content than in the spring. These authors estimated overall means of $3.44 \pm 0.52 \%$ of fat, $2.95 \pm 0.15 \%$ of protein, $4.45 \pm 0.38 \%$ of lactose and $11.69 \pm 0.70 \%$ of total solids. Since these data were obtained from the tank samples and only two lactations, then these means do not accurately characterize the parameters.

The Brazilian Ministry of Agriculture, Livestock and Food Supply establishes minimum requirements for the commercialization of goat milk destined for human consumption, such as fat (original percentage in whole milk and $0.6 \%-2.9 \%$ for semi-skimmed milk), protein (minimum of $2.8 \%$ for all class) and lactose (minimum of $4.3 \%$ for all class; Brasil, 2000). Considering the overall averages calculated with the information of all breeds $(3.69 \%$ fat, $2.91 \%$ protein, and $4.23 \%$ lactose), only lactose is below the minimum recommended for milk commercialization. Proportion of lactose de $4.30 \%$ were reported by Raynal-Ljutovac et al. (2008) for Saanen in UK. Proportions of protein lower than $2.8 \%$ were reported by Clark and Sherbon (2000) for Toggenburg and Alpine $\mathrm{x}$ Saanen crossbred reared in the United States of America. However, the protein average observed in this study, in absolute terms, are below the values estimated for the Saanen breed in Portugal (Trancoso et al., 2010) and Austria (Helmut and Fiechter, 2012). Fat and protein percentages of $3.14 \%$ and $3.14 \%$, respectively, were reported by Olivier et al. (2005) in South Africa for Saanen goats. Our values were higher for fat and lower for protein (except the Anglo Nubian average). In Mexico, also for Saanen, Torres-Vázquez et al. (2010) reported figures of $3.2 \%, 2.8 \%$ and $4.2 \%$ for fat, protein and lactose percentages. This average for lactose was higher than the averages for the breeds of our study, but similar to our global average.

In Brazil, market demand for goat milk is not consolidated and great part of the production is commercialized as fluid milk and it is dependent on governmental acquisition (Rodrigues et al., 2012), by a
Brazilian social program which aims to ensure access to food for people living in food and/or nutritional insecure situation and strengthen family agriculture, through government food purchases. Thus, there is a constraint to the increasing of production and many producers, cooperatives and industries search other alternatives such as the development of dairy products. In this aspect, variability observed in this study for milk components were important and must be considered to the development of dairy goat industry in Brazil. The knowledge about the figures can contribute for the establishment of the levels to development of a system of differential payment to producers and define the selection objectives.

The means of SCC observed in this study were similar to commonly reported in goats. SCC in goat milk can vary between $270 \times 10^{3}$ and $2000 \times 10^{3}$ cells $/ \mathrm{mL}$ (Jimenez-Granado et al., 2014). However, the lower values of SCC for the breeds raised in Northeast regions (Anglo Nubian and Saanen) in comparison to those of Southeast region (Saanen, Alpine and Anglo Nubian) probably are related to the difference in the management of the animals (confinement in Southeast vs semi-confinement in Northeast). Under confinement the animals are more exposed to infections, such as those intramammary, and increase the possibilities of transmission by direct contact. The increase of SCC with the lactation order is related to the growing susceptibility of the does to mastitis, especially those subclinical, over the different lactations. The effects of the month and year of recording on SCC also were important and demonstrate the seasonal fluctuations. Pleguezuelos et al. (2015) reported the significance of the effects of year, herd test date, season, parity, month of lactation, litter size and covariables milk yield, fat and protein contents on SCC. According to Stelwagen and Lacy-Hulbert (1996) once daily milking increases SCC without association with damage to mammary secretory cells. This can explain the higher value of SCC to once daily milking does (Table 4). However the results of the literature do not coincide (Jimenez-Granado et al., 2014).

In Brazil, there is no minimum standard of SCC for goat, but Paes et al. (2003) suggest that $1,000,000$ cells $/ \mathrm{mL}$ can be used as a criterion for microbiological analysis to detect mastitis. In the USA, the established limit to is $1,000,000$ cells $/ \mathrm{mL}$ while there is no recommended legal limit in the European Union (Paape et al., 2007). In goats, the association between mastitis and SCC values is not as simple as in dairy cattle, since non-infectious factors also have great impact, such as intrinsic factors (time and number of lactation, litter size, milking time and number of daily milking) and extrinsic factors (milking routine, 
seasonality and food; Jimenez-Granado et al., 2014). From samples of bulk milk tank, Souza et al. (2009) identified the influence of the flock, type of milking and season effects on the goat's SCC. From samples of bulk milk tank, Souza et al. (2009) identified the influence of the flock and season effects on the goat's SCC. The global average was 779,000 cells/mL. They observed that the type of milking also affects the SCC. The averages were $1,121,000$ cells $/ \mathrm{mL}$ in hand milking and 848,000 cells $/ \mathrm{mL}$ in mechanic milking. In both groups the SCC was lower in winter and higher in autumn. It is important to highlight that our study used individual samples different from the study of Souza et al. (2009) who used bulk milk samples.

It was concluded that the production and composition milk of goats imported into Brazil are influenced by genetics and non-genetic factors (lactation order, flock within breed, etc) and that they differ according to the region where the animals are reared. The LAC these goats are below of the minimum limits established by Brazilian Ministry of Agriculture, Livestock and Food Supply for whole milk. SCC global average is above one million of cells $/ \mathrm{mL}$.

\section{Conflict of interest}

The authors declare they have no conflicts of interest.

\section{Ethical approval}

For this type of study formal consent is not required. All applicable international and national guidelines for the care and use of animals where followed.

\section{Acknowledgments}

The authors acknowledge the contribution of the breeders participating of Capragene", the goat breeders association ("Associação dos Criadores de Caprinos e Ovinos de Minas Gerais" - Caprileite/ ACCOMIG) by the coordination of official recording (Agreement 20300.10/0005-2), the Brazilian Ministry of Agriculture, Livestock and Food Supply and the Brazilian Agricultural Research Corporation (Embrapa) by financial support.

\section{References}

Bélichon, S., Manfredi, E., Piacère, A., 1998. Genetic parameters of dairy traits in the Alpine and Saanen goat breeds. Genet. Select. Evol. 30, 529-534.

Boichard, D., Bouloc, N., Ricordeau, G., Piacere, A., Barillet, F., 1989. Genetic parameters for first lactation dairy traits in the Alpine and Saanen goat breeds. Genet. Select. Evol. 21, 205-215.

Brasil, 2000. Ministry of Agriculture, Livestock and Supply. Agriculture Defense Department. Instruction No. 37 of 31 October 2000 approves the technical regulation of identity and quality of goat's milk. Official Journal Online of the Federative Republic of Brazil, Brasilia, DF, Section 1, 23. http://extranet.agricultura.gov.br/ sislegis-consulta/servlet/VisualizarAnexo?id=1691. (Accessed 5 June 2015).

Ciffoni, E.M.G., 1998. Estudo da produção leiteira de um rebanho de cabras Saanen na região de Curitiba, estado do Paraná. Arquivos de Ciência Veterinária e Zoologia 1, $47-58$.

Clark, S., Sherbon, J.W., 2000. Alphas1-casein, milk composition and coagulation properties of goat milk. Small Rumin. Rese. 38, 123-134.

FAO, 2007. The State of the World's Animal Genetic Resources for Food and Agriculture. Barbara Rischkowsky \& Dafydd Pilling, Rome.

Facó, O., Lôbo, R.N.B., Gouveia, A.M.G., Guimarães, M.P.S.L.M.P., Fonseca, J.F., dos Santos, T.N.M., da Silva, M.A.A., Vasques, L.C.V., 2011. Breeding plan for commercial dairy goat production systems in southern Brazil. Small Rumin. Res. 98, 164-169.

Facó, O., Lôbo R.N.B., Fonseca, J.F., Lôbo, A.M.B.O., Verneque, R.S., Pimentel, C.M.M., Paiva, S.R., 2014. Programa de Melhoramento Genético de Caprinos Leiteiros Capragene ; sumário de avaliação genética - Ano 2014 - raça Saanen. Sobral: Embrapa Caprinos e Ovinos, 30p. Available in http://ainfo.cnptia.embrapa.br/ digital/bitstream/item/147201/1/CNPC-2014-Sumario.pdf.

Gonçalves, H.C., Silva, M.A., Wechsler, F.S., Ramos, A.A., 2001. Fatores genéticos e de meio na produção de leite de caprinos leiteiros da raça Saanen. Revista Brasileira de Zootecnia 59, 719-729.

Gonçalves, H.C., Silva, M.A., Wechsler, F.S., Ramos, A.A., Pulz, L.M., Losi, T.C., 2002. Parâmetros e Tendência Genética da Produção de Leite de Cabra no Brasil. Revista
Brasileira de Zootecnia 23, 2204-2208.

Helmut, K.M., Fiechter, G., 2012. Physicochemical characteristics of goat's milk in Austria-seasonal variations and differences between six breeds. Dairy Sci. Technol. 92 (2), 167-177.

ICAR, 2011. International Agreement of Recording Practices. International Committee for Animal Recording (ICAR), Guidelines approved by the General Assembly held in Riga, Latvia on June 2010.

International Dairy Federation. Milk-Enumeration of somatic cells-Part 2: Guidance on the operation of fluoro-opto-electronic counters. Brussels, Belgium, 2006, 15p. (IDF Standard, 148-2)

International Dairy Federation. Milk and liquid milk products-Guidelines for the application of mid-infrared spectrometry. Brussels, Belgium, 2013, 14p. (IDF Standard, 141).

Irano, N., Bignardi, A.B., Rey, F.S.B., Teixeira, I.A.M.A., Albuquerque, L.G., 2012. Parâmetros genéticos para a produção de leite em caprinos das raças Saanen e Alpina. Revista Ciência Agronômica 43, 376-381.

Ishag, I.A., Abdalla, S.A., Ahmed, M.K.A., 2012. Factors affecting milk production traits of Saanen goat raised undert Sudan semi arid conditions. J. Anim. Feed Res. 1, 435-438.

Jimenez-Granado, R., Sanchez-Rodriguez, M., Arce, C., Rodriguez-Estevez, V., 2014. Factors affecting somatic cell count in dairy goats: a review. Span. J. Agric. Res. 12, $133-150$.

Lôbo, R.N.B., Facó, O., Lôbo, A.M.B.O., Villella, L.C.V., 2010. Brazilian goat breeding programs. Small Rumin. Res. 89, 149-154.

Lobo, A.M.B.O., Lobo, R.N.B., 2015. Desempenho produtivo de raças caprinas especializadas e seus mestiços para produção de leite em regiões tropicais. Embrapa Caprinos e Ovinos, Sobral 57p. Embrapa Caprinos e Ovinos. Documentos 117 Available in. http://ainfo.cnptia.embrapa.br/digital/bitstream/item/138223/1/ CNPC-2015-Doc117.pdf.

Lopes, F.B., 2011. Objetivos e critérios de seleção para dois sistemas de criação de caprinos leiteiros no Brasil, (Thesis). Universidade Federal de Goiás, Escola de Medicina Veterinária e Zootecnia 118f. Available in. https://ppgca.evz.ufg.br/up/ 67/o/Tese2011 Fernando Brito.pdf?1349200405.

Oliveira, H.R., Silva, F.F., Siqueira, O.H.G.B.D., Souza, N.O., Junqueira, V.S., Resende, M.D.V., Borquis, R.R.A., Rodrigues, M.T., 2016. Combining diferent functions to describe milk, fat, and protein yield in goats using Bayesian multiple-trait random regression models. J. Anim. Sci. 94, 1865-1874.

Olivier, J.J., Cloete, S.W.P., Schoeman, S.J., Muller, C.J.C., 2005. Performance testing and recording in meat and dairy goats. Small Rumin. Res. 60, 83-93.

Paape, M.J., Wiggans, G.R., Bannerman, D.D., Thomas, D.L., Sanders, A.H., Contreras, A., Moroni, P., Miller, R.H., 2007. Monitoring goat and sheep milk somatic cell counts. Small Rumin. Res. 68, 114-125.

Paes, P.R.O., Lopes, S.T.A., Lopes, R.S., Kohayagawa, R.K., Takahira, A., Langoni, H., 2003. Effects of administration of vitamin E on mammary health and milk cell counts of first parturition goats experimentally challenged with Staphylococcus aureus. Arquivo Brasileiro de Medicina Veterinária e Zootecnia 55, 15-20.

Pleguezuelos, F.J., De la Fuente, L.F., Gonzalo, C., 2015. Variation in milk yield, contents and incomes according to somatic cell count in a large dairy goat population. J. Adv. Dairy Res. 3, 145. http://dx.doi.org/10.4172/2329-888X.1000145.

Raynal-Ljutovac, K., Lagriffoul, G., Paccard, P., Guillet, I., Chilliard, Y., 2008. Composition of goat and sheep milk products: an update. Small Rumin. Res. 79, 57-72.

Ribeiro, A.C., Queiroz, S.A., Lui, J.F., Ribeiro, S.D.A., Resende, K.T., 2000. Genetic and phenotypic parameters estimates of production traits and genetic trend of milk yield of Saanen goats in Southeast of Brazil. Ars Vet. 16, 198-203.

Ribeiro, L.R., Damasceno, U., Cecato, C.C., Jobim, G.T., Santos, F.A.F., Macedo, L.G.P., 2008. Production, milk composition and blood parameters in goats fed different forages. Arquivo Brasileiro de Medicina Veterinária e Zootecnia 60, 1523-1530.

Rodrigues, N.P.A., Givisiez, P.E.N., Queiroga, R.C.R.E., Azevedo, P.S., Gebreyes, W.A., Oliveira, C.J.B., 2012. Milk adulteration: detection of bovine milk in bulk goat milk produced by smallholders in northeastern Brazil by a duplex PCR assay. J. Dairy Sci. 95, 2749-2752.

Rupp, R., Clément, V., Piacere, A., Robert-Granié, C., Manfredi, E., 2011. Genetic parameters for milk somatic cell score and relationship with production and udder type traits in dairy Alpine and Saanen primiparous goats. J. Dairy Sci. 94, 3629-3634.

Salama, A.A.K., Caja, G., Hamzaoui, S., Badaoui, B., Castro-Costa, A., Façanha, D.A.E. Guilhermino, M.M., Bozzi, R., 2014. Different levels of response to heat stress in dairy goat. Small Rumin. Res. 121, 73-79.

Souza, G.N., Brito, J.R.F., Brito, M.A.V.P., Lange, C., Faria, C.G., Moraes, L.C.D., Fonseca, R.G., Silva, Y.A., 2009. Composition and bulk tank somatic cell counts of milk from dairy goat herds in Southeastern Brazil. Braz. J. Vet. Res. Anim. Sci. 46, 19-24.

Stelwagen, K., Lacy-Hulbert, S.J., 1996. Effect of milking frequency on milk somatic cell count characteristics and mammary secretory cell damage in cows. Am. J. Vet. Res. 57, 902-905.

Tholon, P., 2000. Estudo genético quantitativo de características de importância econômica em caprinos da raça Saanen. Monografia (Graduação em Zootecnia), Universidade Estadual Paulista, Jaboticabal, 54p. Available in http://www.capritec. com.br/pdf/tes04.pdf.

Torres-Vázquez, J.A., Valencia-Posadas, M., Castillo-Juárez, H., Montaldo, H.H., 2010 Genetic and phenotypic trends for milk yield and milk composition traits of Saanen goats from Mexico. Revista Mexicana de Ciencias Pecuarias 1, 337-348.

Trancoso, I.M., Trancoso, M.A., Martins, A.P.L., Roseiro, L.B., 2010. Chemical composition and mineral content of goat milk from four indigenous Portuguese breeds in relation to one foreign breed. Int. J. Dairy Techonol. 63, 516-522. 